Article

\title{
Carbon Nanofibers: A New Adsorbent for Copper Removal from Wastewater
}

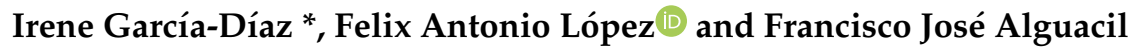 \\ Centro Nacional de Investigaciones Metalúrgicas (CENIM-CSIC), Avda. Gregorio del Amo, 8, 28040 Madrid, \\ Spain; flopez@cenim.csic.es (F.A.L.); fjalgua@cenim.csic.es (F.J.A.) \\ * Correspondence: irenegd@cenim.csic.es; Tel.: +34-91-553-8900
}

Received: 9 October 2018; Accepted: 31 October 2018; Published: 7 November 2018

\begin{abstract}
This research describes the adsorption of $\mathrm{Cu}^{2+}$ onto a helical ribbon carbon nanofiber. The characterization of carbon nanofiber by zeta potential showed an isoelectronic $\mathrm{pH}$ of 1.9. The influence of different adsorption factors, such as stirring speed, temperature, $\mathrm{pH}$, adsorbent concentration, etc., on the $\mathrm{Cu}^{2+}$ adsorption capacity have been evaluated. The $\mathrm{pH}$ has a great influence on $\mathrm{Cu}^{2+}$ adsorption, with the maximum adsorption capacity reached at a $\mathrm{pH}$ of 10 . The experimental data fit well to pseudo-second order kinetic and Langmuir isotherm models $\left(q_{\mathrm{m}}=8.80 \mathrm{mg} \cdot \mathrm{g}^{-1}\right)$ at $T=298 \mathrm{~K}$ and $\mathrm{pH}=4$. The $\mathrm{Cu}^{2+}$ adsorption could be explained by the particle diffusion model. Results showed that carbon nanofiber could be successfully used for the elimination of $\mathrm{Cu}^{2+}$ from wastewater.
\end{abstract}

Keywords: carbon nanofibers; metal adsorption; carbon nanomaterials; copper adsorption; wastewater

\section{Introduction}

Heavy metals are characterized by their high relative densities (greater than $5 \mathrm{~g} \cdot \mathrm{cm}^{-3}$ ) and atomic weights (between 63.5 and 200.6) [1-3]. Though many of these are necessary for life, higher amounts above required levels are hazardous [4].

Moreover, heavy metals are not biodegradable, being easily accumulated in living organisms, particularly in humans. These can cause serious illnesses, such as cancer, damage to the nervous system, increases in blood and respiratory pressure, kidney failure, and could become lethal at high concentrations [1,5-7]. For this reason, the pollution of water due to the presence of heavy metals is a major concern today world-wide. Each year large, volumes of wastewater are produced from different industrial sectors, such as mining, metallurgy and smelting, among others. The most common heavy metals present in wastewaters are nickel, zinc, lead, iron, copper, arsenic, cadmium, and uranium [8-10].

Among these, cooper is considered a harmful metal $[9,11,12]$. There are three forms of copper: $\mathrm{Cu}^{0}$ metal, $\mathrm{Cu}^{+}$cuprous ion, and $\mathrm{Cu}^{2+}$ cupric ion, this last form normally appearing in the environment and considered to be the most toxic of the three $[13,14]$. The main contributors of copper to the environment are mining industries, printing circuits, electroplating industries, paints, fertilizers, plastics and etching, etc. [15-17]. Certain industries that release wastewater into the environment have reported $\mathrm{Cu}^{2+}$ concentrations ranging from $2.0 \mathrm{mg} \cdot \mathrm{L}^{-1}$ to $900 \mathrm{mg} \cdot \mathrm{L}^{-1}$ [18]. Therefore, the recovery of heavy metals, in general, and in particular of copper, is a subject of great social relevance due to the environmental and economic benefits of eliminating contaminates from industrial effluents.

A great number of methods can be used for the recovery or removal of heavy metals from liquid effluents [19]. The choice of one method over another is based mainly on an economic question and metal concentration [1]. Conventional methods include bioremediation [20,21], reverse osmosis [22], electrochemical treatment [23], coagulation [24], precipitation [25,26], 
solvent extraction [27-29], membrane filtration [30,31], electrodialysis [32], supercritical fluids extraction [33,34], ion exchange [35-38], and flotation [39,40].

Adsorption is one of the most popular methods for eliminating heavy metals [41]. It is a technology in which the pollutants, particularly in the case of heavy metals, can interact in a physical or chemical way with the active elements of the adsorbent. Adsorption is a technique that is easy to use and design, and it does not produce contaminants [42]. Moreover, another advantage of the adsorption process is the possibility to regenerate the adsorbent by desorption, being therefore a reversible technique, so it is considered a technology that is not aggressive with the environment. These advantages have made adsorption a leading method for wastewater treatment [13].

Different types of adsorbent have been developed, such as active carbon, clay ore, chelating materials, natural chitosan/zeolites, etc. [19,41,43,44]. In the last twenty years, the interest in nanotechnology has been growing. Materials such as fullerenes, carbon nanotubes, graphene and graphene oxide have a large number of applications in different fields, including the removal of heavy metals from wastewater $[38,45]$. Their unique properties, including high resistance, electrical conductivity and thermal stability, as well as having large specific surface areas, make them sustainable adsorbents for wastewater treatment, and more specifically, for the elimination of heavy metals $[46,47]$

This paper reports the results derived from $\mathrm{Cu}^{2+}$ adsorption on new helix spiral carbon nanofibers (CNF). CNF are structures composed of a helical ribbons of graphene, spiraled about and angled to the fiber axis, similar to the structure of an Archimedes screw with flights inclined to the axis [48].

There are many factors that influence heavy metal adsorption efficiency, such as initial metal concentration, temperature, sorbate amount, $\mathrm{pH}$, and contact time [42,43]. Therefore, the objective of this research was to determine the effects of various experimental variables on $\mathrm{Cu}^{2+}-\mathrm{CNF}$ adsorption systems. Furthermore, kinetic mechanisms, adsorption isotherms models and thermodynamics parameters were investigated.

\section{Materials and Methods}

Carbon nanofibers donated by Antolin group S.A. were used as an adsorbent [49]. Stock metal solution was prepared from $\mathrm{CuSO}_{4}$ (Fluka, Munich, Germany). All other reagents used in the work were analytical reagent grade.

\subsection{Characterization of Carbon Nanofibers}

Carbon nanofibers were examined using a Hitachi S4800 (Tokyo, Japan) scanning electron apparatus equipped with a detectors of secondary, backscattered and transmission electrons, and an Oxford Inca Energy dispersion microanalysis system. Nanomaterials were dispersed in ethanol, and drops of the suspension material were deposited on TEM grating.

The zeta potential was measured using a Zetasizer Malvern Nano ZS (Malvern Panalytical Ltd., Worcestershire, UK) at $25^{\circ} \mathrm{C}$. To study the influence of $\mathrm{pH}$, aqueous suspensions were prepared in $\mathrm{pH}$ solutions between 1 and 13 using solutions of $0.5 \mathrm{M}$ of $\mathrm{HCl}$ and $\mathrm{NaOH}$.

\subsection{Batch Adsorption Experiments}

The batch adsorption experiments were carried out in a $250 \mathrm{~mL}$ glass reactor capable of mechanical (impeller) shaking.

Solutions $(100 \mathrm{~mL})$ containing $\mathrm{Cu}^{2+}$ were used, and weighed amounts of the adsorbent, carbon nanofibers $(\mathrm{CNF})$, were added. The $\mathrm{pH}$ was adjusted using $\mathrm{HCl}$ and $\mathrm{NaOH}$. The residual copper content in the aqueous solution was determined by AAS (Perkin Elmer 1100 B spectrophotometer, Waltham, MA, USA). These were filtered prior to solution analyses. The metal uptake capacity was calculated using Equation (1):

$$
q_{t}=\left(C_{0}-C_{\mathrm{t}}\right) \times \frac{V}{M}
$$


where $q_{\mathrm{t}}$ is the amount metals ions adsorbed $\left(\mathrm{mg} \cdot \mathrm{Cu} \cdot \mathrm{g}^{-1}\right.$ sorbent), while $C_{0}$ and $C_{\mathrm{t}}$ are the initial and contact time metal ion concentrations $\left(\mathrm{mg} \cdot \mathrm{Cu} \cdot \mathrm{L}^{-1}\right)$ in the aqueous solution, respectively. $V$ is the volume of the solution $(0.1 \mathrm{~L})$, and $M$ is the mass of the sorbent $(\mathrm{g})$.

The removal efficiency was calculated using the following equation:

$$
\% \mathrm{Cu}_{\mathrm{ad}}=\left[\left(C_{0}-C_{\mathrm{e}}\right) / C_{\mathrm{e}}\right] \times 100,
$$

where $C_{\mathrm{e}}\left(\mathrm{mg} \cdot \mathrm{Cu} \cdot \mathrm{L}^{-1}\right)$ is the equilibrium metal concentration in solution.

\section{Results}

\subsection{Characterization of $\mathrm{CNF}$}

TEM micrographs of CNF are shown in Figure 1. The helix spiral structure is observed. The structure of $\mathrm{CNF}$ is a continuous cone-helix. The presence of pyrolytic amorphous carbon in the CNF is not observed [49]. CNF structural details are presented in references [48-50]. Table 1 shows the elemental composition.

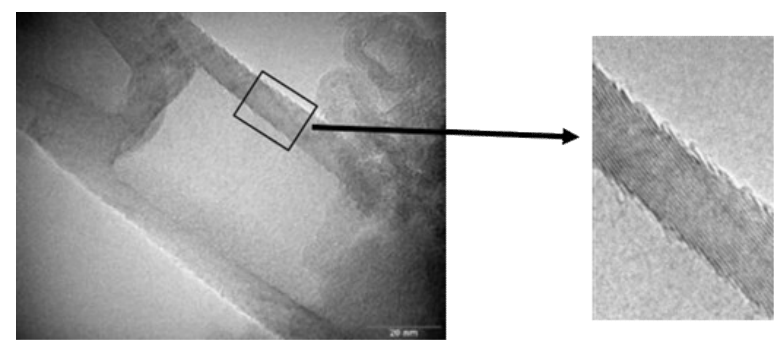

Figure 1. TEM images of carbon nanofibers (CNF) (graphitic structure is observed).

Table 1. CNF elemental analysis (wt \%).

\begin{tabular}{cccccc}
\hline Sample & $\mathbf{C}$ & $\mathbf{H}$ & $\mathbf{N}$ & $\mathbf{S}$ & $\mathbf{O}$ \\
\hline CNF & 99.53 & 0.00 & 0.03 & 0.08 & 0.36 \\
\hline
\end{tabular}

The isoelectric point (IEP) of CNF is obtained at a $\mathrm{pH}$ value of 1.9 (Figure 2). At a $\mathrm{pH}$ values around the $\mathrm{pH}(\mathrm{IEP})$, the sorbent surface charge is neutral. When the $\mathrm{pH}$ value is lower than the isoelectronic point, the sorbent surface has a positive charge, and a negative charge when the $\mathrm{pH}$ is greater than $1.9[37,51]$. The surface charge could affect in the adsorption properties of the adsorbent [51].

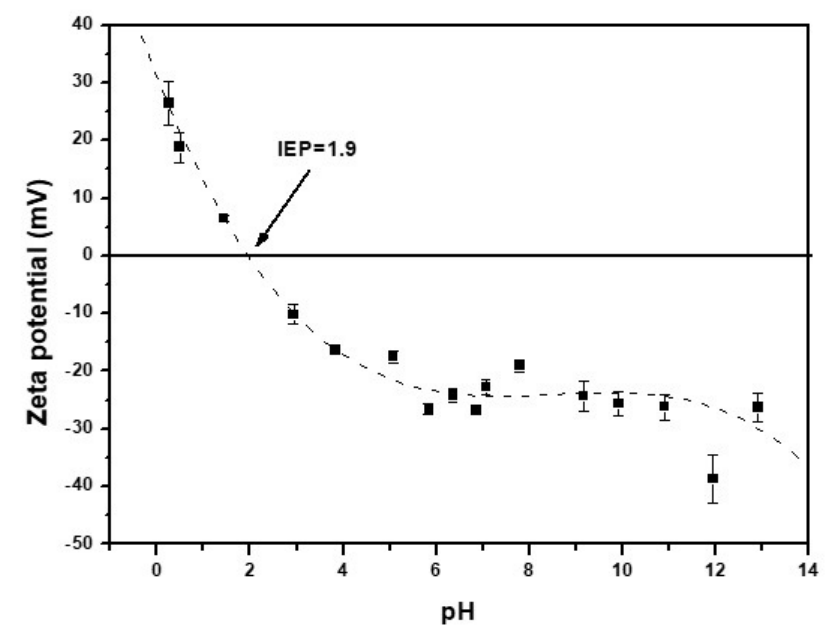

Figure 2. Zeta potential of $\mathrm{CNF}$ versus $\mathrm{pH}$. 


\subsection{Sorption Bach Experiment}

To research the efficiency of the $\mathrm{CNF}$ in $\mathrm{Cu}^{2+}$ adsorption, parameters such as contact time, stirring speed, temperature, $\mathrm{pH}$, carbon nanomaterials concentration, and copper concentration have been studied.

\subsubsection{Effect of the Contact Time and the Stirring Speed}

Figure 3 shows the effect of the contact time on $\mathrm{Cu}^{2+}$ adsorption. The adsorption kinetics was investigated for better understanding of the dynamics of adsorption of metal on the CNF. The removal of $\mathrm{Cu}^{2+}$ between 0-30 min increased sharply, and then tended to became almost stable, which denoted accomplishment of equilibrium at $30 \mathrm{~min}$. From this point, the qt values remained constant. This behavior could be due to the fact that, at the beginning, all of the active sites on the CNF surface were empty and the copper concentration high, and after $30 \mathrm{~min}$, the surface active sites available diminish and the copper concentration lower, so the metal uptake remain constant [52]. The copper adsorption was a quick process.

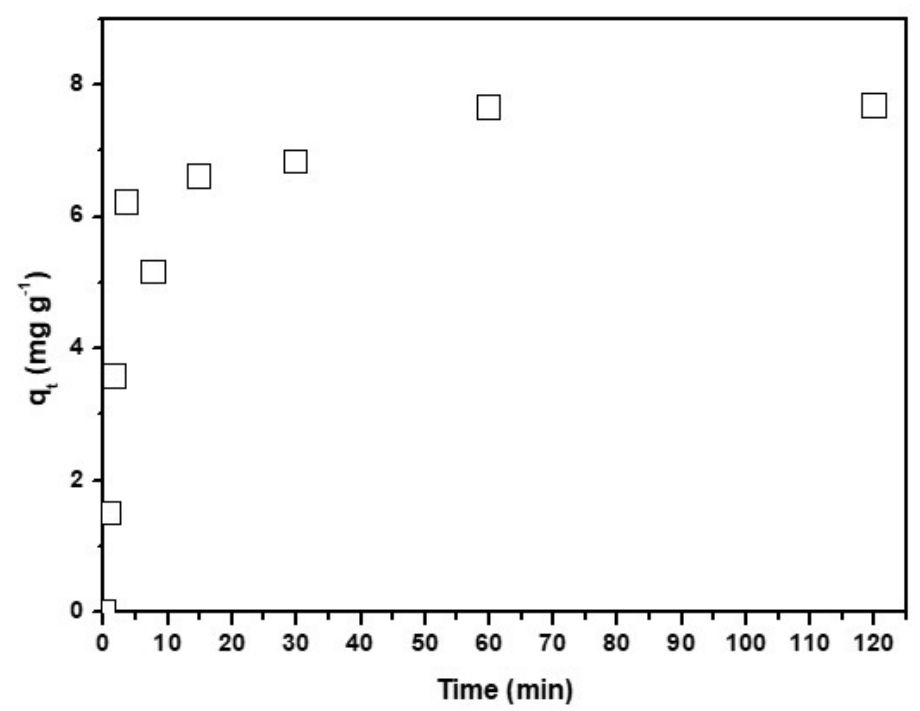

Figure 3. Contact time effect in the adsorption of $\mathrm{Cu}^{2+}$ onto CNF. Experimental conditions: $\mathrm{CNF}=0.1 \mathrm{~g}$, $V=100 \mathrm{~mL}$ of $\left[\mathrm{Cu}^{2+}\right]=0.01 \mathrm{mg} \cdot \mathrm{L}^{-1} \mathrm{pH}=4, T=298 \mathrm{~K}, \theta=500 \mathrm{rpm}$.

The equilibrium time could be decreased by increasing the stirring speed, so the appropriate hydrodynamic conditions were investigated. Table 2 shows that an increase in the stirring speed increased qt values, reaching a maximum between 500-2000 rpm. In this stirring speed interval, the thickness of the aqueous film diffusion layer and the aqueous resistance to mass transfer are at a minimum. An increase in the stirring speed to higher than $2000 \mathrm{rpm}$ decreases the $\mathrm{Cu}^{2+}$ adsorption. This could be due the formation of local equilibrium between the $\mathrm{Cu}^{2+}$ solution and the surrounding $\mathrm{CNF}$ and/or the agglomeration of the nanoparticles.

Table 2. Effect of the stirring speed on the $\mathrm{Cu}^{2+}$ adsorption onto the CNF. Experimental conditions: $\mathrm{CNF}=0.1 \mathrm{~g}, V=100 \mathrm{~mL}$ of $\left[\mathrm{Cu}^{2+}\right]=0.01 \mathrm{mg} \cdot \mathrm{L}^{-1} \mathrm{pH}=4, T=298 \mathrm{~K}, \theta=$ variable.

\begin{tabular}{ccc}
\hline Stirring Speed $(\mathbf{r p m})$ & $\boldsymbol{q}_{\mathrm{e}}\left(\mathbf{m g} \cdot \mathbf{g}^{-\mathbf{1}}\right)$ & Adsorption $\mathbf{( \% )}$ \\
\hline 250 & 5.12 & 51.2 \\
500 & 7.83 & 78.3 \\
1000 & 7.15 & 71.5 \\
2000 & 7.37 & 73.7 \\
3000 & 6.75 & 6.75 \\
\hline
\end{tabular}




\subsubsection{Adsorption Kinetic and Diffusion Mechanism}

To understand the process of $\mathrm{Cu}^{2+}$ adsorption onto CNF, three kinetic adsorption models have been assessed [53]:

(a) pseudo-first order [51]

$$
\ln \left(q_{\mathrm{e}}-q_{\mathrm{t}}\right)=\ln q_{\mathrm{e}}-k_{1} t
$$

(b) pseudo-second order [54]

$$
\frac{t}{q_{\mathrm{t}}}=\frac{1}{k_{2}\left(q_{\mathrm{e}}\right)^{2}}+\frac{1}{q_{\mathrm{e}}} t
$$

(c) Elovich model [55]

$$
q_{\mathrm{t}}=\frac{1}{\beta} \ln \alpha \cdot \beta+\frac{1}{\beta} \ln t
$$

where $q_{\mathrm{e}}$ and $q_{\mathrm{t}}\left(\mathrm{mg} \cdot \mathrm{g}^{-1}\right)$ are the sorption capacities at equilibrium and at time $t$ (min), respectively, $k_{1}$ is first-order adsorption rate constant $\left(\mathrm{min}^{-1}\right)$, and $k_{2}\left(\mathrm{~g} \cdot \mathrm{mg}^{-1} \cdot \mathrm{min}^{-1}\right)$ is the pseudo-second order constant. $\alpha$ is the initial adsorption rate $\left(\mathrm{mg} \cdot \mathrm{min}^{-1}\right)$ at contact time $t=0 \mathrm{~min}$, and $\beta$ is the extent of surface coverage and activated energy $\left(\mathrm{g} \cdot \mathrm{mg}^{-1}\right)$.

According to the calculated data, among the different adsorption reaction models, the higher correlation coefficient, $R^{2}$, was obtained for the pseudo-second order kinetics model (Equation (4) and Table 3). The $q_{\mathrm{e}}$ values derived from the model and the experiment are really similar: $q_{\mathrm{e}}$ (experimental) $6.51 \mathrm{mg} \cdot \mathrm{g}^{-1}[56]$.

Table 3. Kinetic parameters for $\mathrm{Cu}^{2+}$ adsorption onto CNF.

\begin{tabular}{ccccc}
\hline Study & Equation & Constant & $q_{\mathrm{e}}, \boldsymbol{\beta}$ & $\mathbf{R}^{2}$ \\
\hline \multirow{3}{*}{ Kinetic reaction models } & Pseudo-first & $0.0594 \mathrm{~min}^{-1}$ & $q_{\mathrm{e}}=21.04 \mathrm{mg} \cdot \mathrm{g}^{-1}$ & 0.9357 \\
& Pseudo-second & $0.0574 \mathrm{~g} \cdot \mathrm{mg}^{-1} \cdot \mathrm{min}^{-1}$ & $q_{\mathrm{e}}=6.62 \mathrm{mg} \cdot \mathrm{g}^{-1}$ & 0.9985 \\
& Elovich & $\alpha=6.18 \mathrm{mg} \cdot \mathrm{g}^{-1} \cdot \mathrm{min}^{-1}$ & $\beta=8.12 \mathrm{~g} \cdot \mathrm{mg}^{-1}$ & 0.9588 \\
\hline
\end{tabular}

Three adsorption mechanisms have been considered to evaluate the adsorption of $\mathrm{Cu}^{2+}$ on CNF [57,58]:

(a) Film diffusion controlled process: The metal species diffused from the aqueous solution to the CNF surface

$$
\ln \left(1-\frac{q_{\mathrm{t}}}{q_{\mathrm{e}}}\right)=-K t
$$

(b) Particle diffusion controlled process: The ion diffused inside CNF

$$
\ln \left(1-\left(\frac{q_{\mathrm{t}}}{q_{\mathrm{e}}}\right)^{2}\right)=-K t
$$

(c) Moving boundary process

$$
3-3\left(1-\frac{q_{\mathrm{t}}}{q_{\mathrm{e}}}\right)^{\frac{2}{3}}-2 \frac{q_{\mathrm{t}}}{q_{\mathrm{e}}}=K t
$$

where $K\left(\mathrm{~min}^{-1}\right)$ is the rate constant model, $q_{\mathrm{e}}$ and $q_{\mathrm{t}}\left(\mathrm{mg} \cdot \mathrm{g}^{-1}\right)$ are the sorption capacities at equilibrium and contact time, respectively, and $t$ (min).

The results obtained by the kinetic diffusion models show that the $\mathrm{Cu}^{2+}$ adsorption onto the $\mathrm{CNF}$ could be better explained by the particle diffusion model, where $K=0.0525 \mathrm{~min}^{-1}$ (Table 4). 
Table 4. Adsorption mechanism kinetic parameters for $\mathrm{Cu}^{2+}$ adsorption onto CNF.

\begin{tabular}{cccc}
\hline Study & Equation & Constant & $\boldsymbol{R}^{\mathbf{2}}$ \\
\hline \multirow{3}{*}{ Kinetic diffusion models } & Film diffusion & 0.0594 & 0.9375 \\
& Particle diffusion & 0.0525 & 0.9662 \\
& Moving boundary process & -0.0062 & 0.6088 \\
\hline
\end{tabular}

\subsection{3. $\mathrm{pH}$ Influence on $\mathrm{Cu}^{2+}$ Adsorption}

As seen in Figure 4, at a low $\mathrm{pH}$ of two, the adsorption of $\mathrm{Cu}^{2+}$ onto CNF is very low. This is due to the $\mathrm{pH}$ value being very near the zero potential $\mathrm{pH}=1.9$, the charge in the surface being 0 (neutral), and the $\mathrm{Cu}^{2+}$ adsorption being nil or very low. At $\mathrm{pH}$ values lower than two, the potential of the surface charge of the CNF is positive, the cations in solution are repealed from the adsorbent, and it is not adsorbed. When the $\mathrm{pH}$ increases to between 4 and 10, the cooper adsorption increased to its maximum at $\mathrm{pH} 10\left(q_{\mathrm{e}}=8.88 \mathrm{mg} \cdot \mathrm{g}^{-1}\right)$. Above the isoelectronic $\mathrm{pH}$, the nanomaterial surfaces have a negative charge and attract the metal ions facilitating the adsorption $[18,37]$.

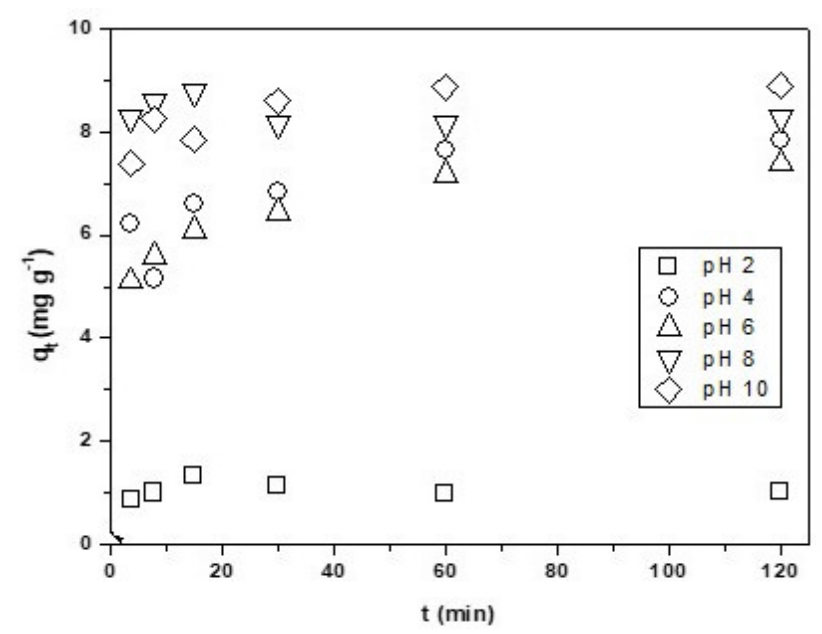

Figure 4. Effect of the $\mathrm{pH}$ on the $\mathrm{Cu}^{2+}$ adsorption onto CNF. Experimental conditions: $\mathrm{CNF}=0.1 \mathrm{~g}$, $V=100 \mathrm{~mL}$ of $\left[\mathrm{Cu}^{2+}\right]=0.01 \mathrm{~g} \cdot \mathrm{L}^{-1} \mathrm{pH}=$ variable, $T=298 \mathrm{~K}, \theta=500 \mathrm{rpm}$.

\subsubsection{Effect of the Copper Concentration}

The adsorption capacity depends on $\mathrm{Cu}^{2+}$ concentration; Table 5 shows an increase in copper concentration in the aqueous phase resulting in a reduction of the recovery percentage. This may be associated with a competitive effect of copper by the active position of the adsorbent.

Table 5. Effect of the $\mathrm{Cu}^{2+}$ concentration on the adsorption onto CNF. Experimental conditions: $\mathrm{CNF}=0.1 \mathrm{~g}, V=100 \mathrm{~mL}$ of $\left[\mathrm{Cu}^{2+}\right]=$ variable, $\mathrm{pH}=4, T=298 \mathrm{~K}, \theta=500 \mathrm{rpm}$.

\begin{tabular}{ccc}
\hline $\mathbf{C u}^{2+}$ Concentration $\left(\mathbf{g} \cdot \mathbf{L}^{-\mathbf{1}}\right)$ & Recovery $(\mathbf{\%})$ & $q_{\mathbf{e}}\left(\mathbf{m g} \cdot \mathbf{g}^{-\mathbf{1}}\right)$ \\
\hline 0.005 & 99.00 & 4.95 \\
0.01 & 76.67 & 7.67 \\
0.02 & 42.25 & 8.45 \\
0.04 & 21.92 & 8.77 \\
\hline
\end{tabular}

The adsorption equilibrium data of the $\mathrm{Cu}^{2+}-\mathrm{CNF}$ system were checked in terms of three isotherm models: Langmuir, Freundlich, Dubinin-Radushkevich and Temkin [59]. The following equations have been used: 
(a) Langmuir [60,61]:

$$
\begin{gathered}
\frac{C_{\mathrm{e}}}{q_{\mathrm{e}}}=\frac{1}{q_{\mathrm{m}} b}+\frac{1}{q_{\mathrm{m}}} C_{\mathrm{e}} \\
R_{\mathrm{L}}=\frac{1}{1+b C_{0}}
\end{gathered}
$$

(b) Freundlich [62]:

$$
\ln q_{\mathrm{e}}=\ln K_{\mathrm{F}}+\frac{1}{n} \ln C_{\mathrm{e}}
$$

where $q_{\mathrm{e}}\left(\mathrm{mg} \cdot \mathrm{g}^{-1}\right)$ is the sorption capacities at equilibrium time, $C_{\mathrm{e}}\left(\mathrm{mg} \cdot \mathrm{L}^{-1}\right)$ is the metal ion concentration in the aqueous phase at equilibrium, $q_{\mathrm{m}}\left(\mathrm{mg} \cdot \mathrm{g}^{-1}\right)$ is maximum sorption capacity, and $b\left(\mathrm{~L} \cdot \mathrm{mg}^{-1}\right)$ is the Langmuir sorption constant. $R_{\mathrm{L}}$ is a dimensional constant separation [63]. $C_{0}$ $\left(\mathrm{mg} \cdot \mathrm{L}^{-1}\right)$ is the maximun initial copper concentration. $K_{\mathrm{F}}$ is the Freundlich constant $\left(\mathrm{L} \cdot \mathrm{g}^{-1}\right)$, and $1 / n$ is a heterogeneity factor constant, their values must be less than one for favorable adsorption.

(c) Dubinin-Radushkevich [64]:

$$
\ln q_{\mathrm{e}}=\ln q_{\mathrm{d}}-K \cdot \varepsilon^{2}
$$

where:

$$
\begin{gathered}
\varepsilon=R T \ln \left(1+\frac{1}{C_{e}}\right) \\
E=\frac{1}{\sqrt{2 \cdot K}}
\end{gathered}
$$

where $q_{\mathrm{e}}$ are $\mathrm{mg} \cdot \mathrm{g}^{-1}$ in equilibrium, $q_{\mathrm{d}}$ is the theoretical capacity adsorption $\left(\mathrm{mg} \cdot \mathrm{g}^{-1}\right), K$ is a constant related to the mean free energy in the adsorption $\left(\mathrm{mol}^{2} \cdot \mathrm{J}^{-2}\right)$ and $E\left(\mathrm{KJ} \cdot \mathrm{mol}^{-1}\right)$ [63]. $\varepsilon$ is the Polanyi adsorption potential, $R$ is the universal gas constant $\left(8.314 \mathrm{~J} \cdot \mathrm{K}^{-1} \cdot \mathrm{mol}^{-1}\right), T$ is the temperature in $K$, and $C_{\mathrm{e}}$ is the metal ion concentration in the aqueous phase at equilibrium in $\mathrm{mg} \cdot \mathrm{L}^{-1}$.

(d) Temkin [65]:

$$
q_{\mathrm{e}}=B \cdot \ln \left(K_{\mathrm{T}}+C_{\mathrm{e}}\right)
$$

where $q_{\mathrm{e}}$ is the sorption capacities at equilibrium time in mol. $\mathrm{g}^{-1}, \mathrm{C}_{\mathrm{e}}$ is the metal ion concentration in the aqueous phase at equilibrium in mol. $\mathrm{L}^{-1}$, and $K_{\mathrm{T}}$ is the isotherm equilibrium binding constant $\left(\mathrm{L} \cdot \mathrm{g}^{-1}\right) ; B$ is a constant related to the sorption heat in $\mathrm{J} \cdot \mathrm{mol}^{-1}$.

According to the values of the correlation coefficient, $R^{2}$, the experimental results fit well to the studied isotherms, Table 6 . However, the best fit is obtained for the Langmuir model. The $q_{\mathrm{m}}$ value obtained from this model is similar to the experimental one, $8.77 \mathrm{mg} \cdot \mathrm{g}^{-1}$. The separation factor, $R_{\mathrm{L}}$, shows that the adsorption process is favorable if the $R_{\mathrm{L}}$ value is $0<R_{\mathrm{L}}<1$, unfavorable when $R_{\mathrm{L}}>1$, linear when $R_{\mathrm{L}}=1$, and irreversible at values of $R_{\mathrm{L}}=0$. The $\mathrm{Cu}^{2+}$ adsorption on CNF is favorable with a $R_{\mathrm{L}}$ value between zero and one, the value here being $5.6 \times 10^{-3}$. The $1 / n$ value obtained from adjusting the data to the Freundlich isotherm is $9.12 \times 10^{-2}$, also indicating that the copper adsorption on $\mathrm{CNF}$ is favorable.

Table 6. Calculated isotherms parameters. Experimental conditions: $\mathrm{CNF}=0.1 \mathrm{~g}, V=100 \mathrm{~mL}$ of $\left[\mathrm{Cu}^{2+}\right]$ $=$ variable $\mathrm{pH}=4, T=298 \mathrm{~K}, \theta=500 \mathrm{rpm}$.

\begin{tabular}{ccccccc}
\hline & \multicolumn{2}{c}{ Langmuir Model } & \multicolumn{4}{c}{ Freundlich Model } \\
\hline$q_{\mathrm{m}}$ & $b$ & $R_{\mathrm{L}} \times 10^{-3}$ & $R^{2}$ & $n$ & $K_{\mathrm{F}}$ & $R^{2}$ \\
8.80 & 4.44 & 5.6 & 0.9998 & 10.96 & 0.15 & 0.9456 \\
\hline \multicolumn{3}{c}{ Dubinin-Raduskevich } & \multicolumn{3}{c}{ Temkin } \\
\hline$q_{\mathrm{d}}$ & $K$ & $E$ & $R^{2}$ & $K_{\mathrm{T}}$ & $B$ & $R^{2}$ \\
8.38 & $9.28 \times 10^{-9}$ & 7.34 & 0.9765 & 97.26 & 0.61 & 0.9640 \\
\hline
\end{tabular}


The energy value calculated using the Dubinin-Raduskevich model was $E=7.34\left(\mathrm{KJ} \cdot \mathrm{mol}^{-1}\right)$. This is lower than $8 \mathrm{KJ} \cdot \mathrm{mol}^{-1}$, which indicates that the mechanism of adsorption has a physical nature [63].

\subsubsection{Effect of the CNF Dosage}

The CNF dosage was modified in order to evaluate the effect of this parameter. It was expected that an increase in the CNF dosage will increase the adsorption percentage and diminish the adsorption capacity values.

The objective of this research was to achieve the highest possible metal recovery. The best result was obtained using $0.2 \mathrm{~g}$ of CNF, with $97 \%$ of the copper recovered (see Table 7 ).

Table 7. Effect $\mathrm{CNF}$ concentration. Experimental conditions: $\mathrm{CNF}=$ variable, $V=100 \mathrm{~mL}$ of $\left[\mathrm{Cu}^{2+}\right]=$ $0.01 \mathrm{mg} \cdot \mathrm{L}^{-1}, \mathrm{pH}=4, \mathrm{~T}=298 \mathrm{~K}, \theta=500 \mathrm{rpm}$.

\begin{tabular}{ccc}
\hline CNF Concentration $(\mathrm{g})$ & Recovery $(\mathbf{\%})$ & $\boldsymbol{q}_{\mathrm{e}}\left(\mathbf{m g} \cdot \mathbf{g}^{-\mathbf{1}}\right)$ \\
\hline 0.05 & 29.06 & 5.81 \\
0.08 & 52.10 & 6.51 \\
0.1 & 76.67 & 7.67 \\
0.2 & 96.69 & 4.83 \\
\hline
\end{tabular}

\subsubsection{Temperature Influence and Thermodynamic Studies}

The influence of the temperature (293-333 K) on $\mathrm{Cu}^{2+}$ adsorption on $\mathrm{CNF}$ have been studied. The assay conditions were $0.01 \mathrm{~g} \cdot \mathrm{L}^{-1}$ of $\mathrm{Cu}(\mathrm{II}), 4 \mathrm{pH}, 0.1 \mathrm{~g}$ of CNF adsorbent, and a stirring speed of $500 \mathrm{rpm}$. Figure 5 shows the variation of $q_{\mathrm{t}}$ vs. $t$.

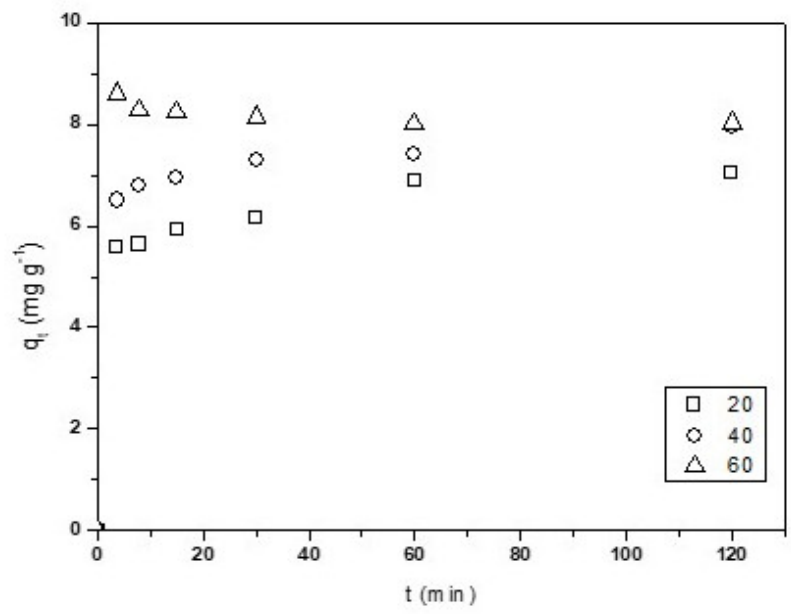

Figure 5. Temperature effect on the variation of $q_{\mathrm{t}}\left(\mathrm{mg} \cdot \mathrm{g}^{-1}\right)$ vs. time.

An increase of the $q_{\mathrm{e}}$ value with temperature was observed, having reached a maximum at $333 \mathrm{~K}, 8 \mathrm{mg} \cdot \mathrm{g}^{-1}$. Therefore, the process is considered endothermic. The increase of adsorption with temperature can be due to different factors, such as a change in the pore size of the nanofibers and/or an increase of the active sites. In addition, the collisions between the metal and the surface of the nanofibers are greater, thereby contributing to a rise in the adsorption capacity [18].

The experimental data obtained at different temperatures (293-333 K) was used to calculate the thermodynamics parameters, $\Delta H^{\circ}, \Delta G^{\circ}$, and $\Delta S^{\circ}$, using the following equation:

$$
\ln K_{\mathrm{d}}=\frac{\Delta S^{\circ}}{R}-\frac{\Delta H^{\circ}}{R T}
$$

where $\Delta S^{\circ}$ is the entropy of the reaction, $\Delta H^{\circ}$ is the enthalpy, $T$ is the temperature in Kelvin, and $R$ is the universal gas constant $\left(8.314 \mathrm{~J} \cdot \mathrm{K}^{-1} \cdot \mathrm{mol}^{-1}\right) . K_{\mathrm{d}}$ is defined as follows: 


$$
K_{\mathrm{d}}=\frac{q_{\mathrm{e}}}{C_{\mathrm{e}}}
$$

where $q_{\mathrm{e}},\left(\mathrm{mg} \cdot \mathrm{g}^{-1}\right)$ and $C_{\mathrm{e}}\left(\mathrm{mg} \cdot \mathrm{L}^{-1}\right)$ are the equilibrium capacity on the solid and the liquid phases, respectively. Plotting the linear fit $\ln \frac{\mathrm{C}_{\mathrm{e}}, \mathrm{CNF}}{\mathrm{C}_{\mathrm{e}}}$ vs. $\frac{1}{T}$ to the slope could be used to calculate the $\Delta H^{\circ}$ value (Table 8).

Table 8. Thermodynamic parameters for $\mathrm{Cu}^{2+}-\mathrm{CNF}$ system.

\begin{tabular}{|c|c|c|c|c|}
\hline \multicolumn{5}{|c|}{ Thermodynamic Parameters } \\
\hline$\Delta H^{\circ}\left(\mathrm{KJ} \cdot \mathrm{mol}^{-1}\right)$ & $\Delta S^{\circ}\left(\mathrm{J} \cdot \mathrm{mol}^{-1}\right)$ & & $(\mathrm{KJ} \cdot \mathrm{mo}$ & \\
\hline 26.76 & 100.93 & $\begin{array}{l}293 \mathrm{~K} \\
-3.07\end{array}$ & $\begin{array}{l}313 \mathrm{~K} \\
-4.24\end{array}$ & $\begin{array}{c}333 \mathrm{~K} \\
-7.18\end{array}$ \\
\hline
\end{tabular}

For the entire temperature range studied, the $\Delta G^{\circ}$ values were negative, this indicating that the adsorption process is spontaneous. These values are lower than $18 \mathrm{KJ} \cdot \mathrm{mol}^{-1}$, characteristic of a physisorption [18], and this agrees with the result obtained from $\mathrm{R}_{\mathrm{L}}$ Langmuir parameter (see Table 6).

The positive enthalpy confirms the endothermic behavior of $\mathrm{Cu}^{2+}$ adsorption on the CNF. The $\Delta S^{\circ}$ value is positive, which indicates an increase in the randomness in the $\mathrm{CNF} / \mathrm{Cu}^{2+}$ system. In the temperature range studied, the $\Delta H^{\circ}$ is lower than $\mathrm{T} \cdot \Delta S^{\circ}$, so the sorption process was dominated by entropic rather than enthalpic changes [51,62].

\subsection{7. $\mathrm{Cu}^{2+}$ Elution}

According to the results for $\mathrm{Cu}^{2+}$ adsorption on $\mathrm{CNF}$, it is expected that an increase in the acid concentration changes the adsorption conditions, and $\mathrm{Cu}^{2+}$ could then be eluted. The effect of the acid concentration in elution was studied. For $30 \mathrm{~min}, 0.05 \mathrm{~g}$ of CNF load with $4.83 \mathrm{mg} \cdot \mathrm{g}^{-1} \mathrm{of} \mathrm{Cu}^{2+}$ were put in contact with $20 \mathrm{~mL}$ of $\mathrm{H}_{2} \mathrm{SO}_{4}$ in solutions of different concentrations at a stirring speed of $500 \mathrm{rpm}$.

An increase in the acid concentration increased the elution percentage (see Table 9), reaching a percentage of around $96 \%$ with a $\mathrm{H}_{2} \mathrm{SO}_{4}$ concentration of $4 \mathrm{M}$. The kinetic elution study was performed using a solution of $2 \mathrm{M}$ sulfuric acid, with equilibrium reached after $15 \mathrm{~min}$. The elution kinetics was faster than the adsorption.

Table 9. Elution percentage.

\begin{tabular}{cccc}
\hline $\mathbf{H}_{\mathbf{2}} \mathbf{S O}_{\mathbf{4}}$ Concentration & $\mathbf{1} \mathbf{M}$ & $\mathbf{2} \mathbf{M}$ & $\mathbf{4} \mathbf{M}$ \\
\hline Elution recovery (\%) & 38.42 & 46.12 & 96.36 \\
\hline
\end{tabular}

\section{Conclusions}

The results obtained in this research prove that helical carbon nanofibers are a potential adsorbent of $\mathrm{Cu}^{2+}$ from wastewaters. Of the parameters studied, $\mathrm{pH}$ has the greatest influence on copper adsorption capacity, reaching a maximum $q_{\mathrm{m}}$ value of around $8.80 \mathrm{mg} \cdot \mathrm{g}^{-1}$ at a $\mathrm{pH}$ value of 10 . An increase in the temperature does not influence the adsorption capacity; however, the equilibrium is reached in less time.

The $\mathrm{Cu}^{2+}$ kinetics fitted a pseudo-second order $\left(0.0574 \mathrm{~g} \cdot \mathrm{mg}^{-1} \cdot \mathrm{min}^{-1}\right)$. The $\mathrm{Cu}^{2+}$ adsorption is considered a particle diffusion controlled process. The experimental data adjusted to a Langmuir model, the $q_{\mathrm{m}}=8.80 \mathrm{mg} \cdot \mathrm{g}^{-1}$, is a favorable, endothermic $\left(\Delta H^{\circ}=26.76 \mathrm{KJ} \cdot \mathrm{mol}^{-1}\right)$ and physical nature adsorption. Metal elution was carried out with a $\mathrm{H}_{2} \mathrm{SO}_{4} 4 \mathrm{M}$ solution, at $30 \mathrm{~min}$, reaching an elution percentage of $96 \%$. 
Author Contributions: Investigation, methodology, formal analysis, writing original draft, validation: I.G.-D., investigation, supervision, writing-review and editing: F.A.L., investigation, supervision, writing-review and editing: F.J.A.

Funding: This research received no external funding.

Acknowledgments: To CSIC Agency (Spain) for support.

Conflicts of Interest: The authors declare no conflict of interest.

\section{References}

1. Abbas, A.; Al-amer, A.M.; Laoui, T.; Al-marri, M.J.; Nasser, M.S.; Khraisheh, M.; Ali, M. Heavy metal removal from aqueous solution by advanced carbon nanotubes: Critical review of adsorption applications. Sep. Purif. Technol. 2016, 157, 141-161.

2. Srivastava, N.K.; Majumder, C.B. Novel biofiltration methods for the treatment of heavy metals from industrial wastewater. J. Hazard. Mater. 2008, 151, 1-8. [CrossRef] [PubMed]

3. Barakat, M.A. New trends in removing heavy metals from industrial wastewater. Arab. J. Chem. 2011, 4, 361-377. [CrossRef]

4. Tchounwou, P.B.; Yedjou, C.G.; Patlolla, A.K.; Sutton, D.J. Heavy Metal Toxicity and the Environment. In Molecular, Clinical and Environmental Toxicology; Springer: Basel, Switzerland, 2012; Volume 101, pp. 133-164.

5. Bertinato, J.; Abbe, M.R.L. Maintaining copper homeostasis: Regulation of copper-trafficking proteins in response to copper deficiency or overload. J. Nutr. Biochem. 2004, 15, 316-322. [CrossRef] [PubMed]

6. Chen, Z.; Meng, H.; Xing, G.; Chen, C.; Zhao, Y.; Jia, G.; Wang, T.; Yuan, H.; Ye, C.; Zhao, F.; et al. Acute toxicological effects of copper nanoparticles in vivo. Toxicol. Lett. 2006, 163, 109-120. [CrossRef] [PubMed]

7. Tyler Mehler, W.; Gagliardi, B.; Keough, M.J.; Pettigrove, V. Evaluating freshwater mining sediment toxicity in Tasmania: Achieving strong multiple lines of evidence. Sci. Total Environ. 2019, 651, 1243-1252. [CrossRef] [PubMed]

8. Taoufiq, L.; Laamyem, A.; Monkade, M.; Zradba, A. Characterization and Application of Solid Waste in the Adsorption of Heavy metals. J. Mater. Environ. Sci. 2016, 7, 4646-4656.

9. Al-Saydeh, S.A.; El-Naas, M.H.; Zaidi, S.J. Copper removal from industrial wastewater: A comprehensive review. J. Ind. Eng. Chem. 2017, 56, 35-44. [CrossRef]

10. Jayaweera, H.D.A.C.; Siriwardane, I.; de Silva, K.M.N.; de Silva, R.M. Synthesis of multifunctional activated carbon nanocomposite comprising biocompatible flake nano hydroxyapatite and natural turmeric extract for the removal of bacteria and lead ions from aqueous solution. Chem. Cent. J. 2018, 12, 18. [CrossRef] [PubMed]

11. Nassef, E. Removal of Copper From Wastewater By Cementation From Simulated Leach Liquors. J. Chem. Eng. Process Technol. 2015, 6, 214. [CrossRef]

12. Yang, S.; Ren, X.; Zhao, G.; Shi, W.; Montavon, G.; Grambow, B.; Wang, X. Competitive sorption and selective sequence of $\mathrm{Cu}(\mathrm{II})$ and $\mathrm{Ni}(\mathrm{II})$ on montmorillonite: Batch, modeling, EPR and XAS studies. Geochim. Cosmochim. Acta 2015, 166, 129-145. [CrossRef]

13. Carolin, C.F.; Kumar, P.S.; Saravanan, A.; Joshiba, G.J.; Naushad, M. Efficient techniques for the removal of toxic heavy metals from aquatic environment: A review. J. Environ. Chem. Eng. 2017, 5, 2782-2799. [CrossRef]

14. Awual, M.R.; Ismael, M.; Khaleque, M.A.; Yaita, T. Ultra-trace copper(II) detection and removal from wastewater using novel meso-adsorbent. J. Ind. Eng. Chem. 2014, 20, 2332-2340. [CrossRef]

15. Trakal, L.; Šigut, R.; Šillerová, H.; Faturíková, D.; Komárek, M. Copper removal from aqueous solution using biochar: Effect of chemical activation. Arab. J. Chem. 2014, 7, 43-52. [CrossRef]

16. Howard, P.H.; Muir, D.C.G. Identifying New Persistent and Bioaccumulative Organics among Chemicals in Commerce. Environ. Sci. Technol. 2010, 44, 2277-2285. [CrossRef] [PubMed]

17. Zou, Y.; Wang, X.; Khan, A.; Wang, P.; Liu, Y.; Alsaedi, A.; Hayat, T.; Wang, X. Environmental Remediation and Application of Nanoscale Zero-Valent Iron and Its Composites for the Removal of Heavy Metal Ions: A Review. Environ. Sci. Technol. 2016, 50, 7290-7304. [CrossRef] [PubMed]

18. Zepeda, A.M.; Gonzalez, D.; Heredia, L.G.; Marquez, K.; Perez, C.; Pena, E.; Flores, K.; Valdes, C.; Eubanks, T.M.; Parsons, J.G.; et al. Removal of $\mathrm{Cu}^{2+}$ and $\mathrm{Ni}^{2+}$ from aqueous solution using $\mathrm{SnO}_{2}$ nanomaterial effect of: $\mathrm{pH}$, time, temperature, interfering cations. Microchem. J. 2018, 141, 188-196. [CrossRef] 
19. Fu, F.; Wang, Q. Removal of heavy metal ions from wastewaters: A review. J. Environ. Manag. 2011, 92, 407-418. [CrossRef] [PubMed]

20. Fernández, P.M.; Viñarta, S.C.; Bernal, A.R.; Cruz, E.L.; Figueroa, L.I.C. Bioremediation strategies for chromium removal: Current research, scale-up approach and future perspectives. Chemosphere 2018, 208, 139-148. [CrossRef] [PubMed]

21. Tiquia-Arashiro, S.M. Lead absorption mechanisms in bacteria as strategies for lead bioremediation. Appl. Microbiol. Biotechnol. 2018, 102, 5437-5444. [CrossRef] [PubMed]

22. MLayah, A.; Jellali, S. Study of continuous lead removal from aqueous solutions by marble wastes: Efficiencies and mechanisms. Int. J. Environ. Sci. Technol. 2015, 12, 2965-2978. [CrossRef]

23. Matsumiya, M.; Sumi, M.; Uchino, Y.; Yanagi, I. Recovery of indium based on the combined methods of ionic liquid extraction and electrodeposition. Sep. Purif. Technol. 2018, 201, 25-29. [CrossRef]

24. Zhang, P.; Hahn, H.H.; Hoffmann, E. Different Behavior of Iron(III) and Aluminum(III) Salts To Coagulate Silica Particle Suspension. Acta Hydrochim. Hydrobiol. 2003, 31, 145-151. [CrossRef]

25. Boamah, P.O.; Huang, Y.; Hua, M.; Zhang, Q.; Wu, J.; Onumah, J.; Sam-Amoah, L.K.; Boamah, P.O. Sorption of heavy metal ions onto carboxylate chitosan derivatives-A mini-review. Ecotoxicol. Environ. Saf. 2015, 116, 113-120. [CrossRef] [PubMed]

26. Wang, L.K.; Vaccari, D.A.; Li, Y.; Shammas, N.K. Chemical Precipitation. In Physicochemical Treatment Processes; Humana Press: Totowa, NJ, USA, 2005; pp. 141-197.

27. Alguacil, F.J.; Garcia-Diaz, I.; Lopez, F.; Rodriguez, O. Recycling of copper flue dust via leaching-solvent extraction processing. Desalin. Water Treat. 2015, 56. [CrossRef]

28. Ye, Q.; Li, G.; Deng, B.; Luo, J.; Rao, M.; Peng, Z.; Zhang, Y.; Jiang, T. Solvent extraction behavior of metal ions and selective separation $\mathrm{Sc}^{3+}$ in phosphoric acid medium using P204. Sep. Purif. Technol. 2019, 209, 175-181. [CrossRef]

29. Wang, L.Y.; Guo, Q.J.; Lee, M.S. Recent advances in metal extraction improvement: Mixture systems consisting of ionic liquid and molecular extractant. Sep. Purif. Technol. 2019, 210, 292-303. [CrossRef]

30. Ersahin, M.E.; Ozgun, H.; Dereli, R.K.; Ozturk, I.; Roest, K.; van Lier, J.B. A review on dynamic membrane filtration: Materials, applications and future perspectives. Bioresour. Technol. 2012, 122, 196-206. [CrossRef] [PubMed]

31. Ma, H.; Kökkılıç, O.; Waters, K.E. The use of the emulsion liquid membrane technique to remove copper ions from aqueous systems using statistical experimental design. Miner. Eng. 2017, 107, 88-99. [CrossRef]

32. Gherasim, C.-V.; Křivčík, J.; Mikulášek, P. Investigation of batch electrodialysis process for removal of lead ions from aqueous solutions. Chem. Eng. J. 2014, 256, 324-334. [CrossRef]

33. Kanari, N.; Allain, E.; Joussemet, R.; Mochón, J.; Ruiz-Bustinza, I.; Gaballah, I. An overview study of chlorination reactions applied to the primary extraction and recycling of metals and to the synthesis of new reagents. Thermochim. Acta 2009, 495, 42-50. [CrossRef]

34. Burford, M.D.; Ozel, M.Z.; Clifford, A.A.; Bartle, K.D.; Lin, Y.; Wai, C.M.; Smart, N.G. Extraction and recovery of metals using a supercritical fluid with chelating agents. Analyst 1999, 124, 609-614. [CrossRef]

35. Motsi, T.; Rowson, N.A.; Simmons, M.J.H. Adsorption of heavy metals from acid mine drainage by natural zeolite. Int. J. Miner. Process. 2009, 92, 42-48. [CrossRef]

36. Alguacil, F.J. La eliminación de metales tóxicos presentes en efluentes líquidos mediante resinas de cambio iónico. Parte IV: Cromo(III)/H+/Lewatit SP112. Rev. Metal. 2017, 53, 093. [CrossRef]

37. Alguacil, F.; Alcaraz, L.; García-Díaz, I.; López, F. Removal of Pb2+ in Wastewater via Adsorption onto an Activated Carbon Produced from Winemaking Waste. Metals 2018, 8, 697. [CrossRef]

38. Alguacil, F.J.; Lopez, F.A.; Rodriguez, O.; Martinez-Ramirez, S.; Garcia-Diaz, I. Sorption of indium (III) onto carbon nanotubes. Ecotoxicol. Environ. Saf. 2016, 130. [CrossRef] [PubMed]

39. Smolinski, T.; Wawszczak, D.; Deptula, A.; Lada, W.; Olczak, T.; Rogowski, M.; Pyszynska, M.; Chmielewski, A.G. Solvent extraction of $\mathrm{Cu}, \mathrm{Mo}, \mathrm{V}$, and $\mathrm{U}$ from leach solutions of copper ore and flotation tailings. J. Radioanal. Nucl. Chem. 2017, 314, 69-75. [CrossRef] [PubMed]

40. Zhang, H.; Tangparitkul, S.; Hendry, B.; Harper, J.; Kim, Y.K.; Hunter, T.N.; Lee, J.W.; Harbottle, D. Selective separation of cesium contaminated clays from pristine clays by flotation. Chem. Eng. J. 2019, 355, 797-804. [CrossRef]

41. Lu, F.; Astruc, D. Nanomaterials for removal of toxic elements from water. Coord. Chem. Rev. 2018, 356, 147-164. [CrossRef] 
42. Burakov, A.E.; Galunin, E.V.; Burakova, I.V.; Kucherova, A.E.; Agarwal, S.; Tkachev, A.G.; Gupta, V.K. Adsorption of heavy metals on conventional and nanostructured materials for wastewater treatment purposes: A review. Ecotoxicol. Environ. Saf. 2018, 148, 702-712. [CrossRef] [PubMed]

43. Renu; Agarwal, M.; Singh, K. Heavy metal removal from wastewater using various adsorbents: A review. J. Water Reuse Desalin. 2017, 7, 387-419. [CrossRef]

44. Alguacil, F.J.; Lopez, F.A.; Garcia-Diaz, I. Extracting metals from aqueous solutions using Ti-based nanostructures: A review. Desalin. Water Treat. 2016, 57. [CrossRef]

45. Salam, M.A.; Makki, M.S.I.; Abdelaal, M.Y.A. Preparation and characterization of multi-walled carbon nanotubes/chitosan nanocomposite and its applicaton for removal of heavy metals from aqueous solution. J. Alloy. Compd. 2011, 509, 2582-2587. [CrossRef]

46. Matos, M.P.S.R.; Correia, A.A.S.; Rasteiro, M.G. Application of carbon nanotubes to immobilize heavy metals in contaminated soils. J. Nanopart. Res. 2017, 19, 126. [CrossRef]

47. Bhatia, M.; Satish Babu, R.; Sonawane, S.H.; Gogate, P.R.; Girdhar, A.; Reddy, E.R.; Pola, M. Application of nanoadsorbents for removal of lead from water. Int. J. Environ. Sci. Technol. 2017, 14, 1135-1154. [CrossRef]

48. Weisenberger, M.; Martin-Gullon, I.; Vera-Agullo, J.; Varela-Rizo, H.; Merino, C.; Andrews, R.; Qian, D.; Rantell, T. The effect of graphitization temperature on the structure of helical-ribbon carbon nanofibers. Carbon 2009, 47, 2211-2218. [CrossRef]

49. Vera-Agullo, J.; Varela-Rizo, H.; Conesa, J.A.; Almansa, C.; Merino, C.; Martin-Gullon, I. Evidence for growth mechanism and helix-spiral cone structure of stacked-cup carbon nanofibers. Carbon 2007, 45, 2751-2758. [CrossRef]

50. Tanaka, A.; Yoon, S.-H.; Mochida, I. Preparation of highly crystalline nanofibers on Fe and Fe-Ni catalysts with a variety of graphene plane alignments. Carbon 2004, 42, 591-597. [CrossRef]

51. Galhoum, A.A.; Atia, A.A.; Mahfouz, M.G.; Abdel-Rehem, S.T.; Gomaa, N.A.; Vincent, T.; Guibal, E. Dy(III) recovery from dilute solutions using magnetic-chitosan nano-based particles grafted with amino acids. J. Mater. Sci. 2015, 50, 2832-2848. [CrossRef]

52. Liang, S.; Guo, X.; Feng, N.; Tian, Q. Isotherms, kinetics and thermodynamic studies of adsorption of $\mathrm{Cu}^{2+}$ from aqueous solutions by $\mathrm{Mg}^{2+} / \mathrm{K}+$ type orange peel adsorbents. J. Hazard. Mater. 2010, 174, 756-762. [CrossRef] [PubMed]

53. Cheung, C.; Porter, J.; Mckay, G. Sorption kinetic analysis for the removal of cadmium ions from effluents using bone char. Water Res. 2001, 35, 605-612. [CrossRef]

54. Ho, Y.S.; Mckay, G. The kinetics of sorption of basic dyes from aqueous solution by sphagnum moss peat. Can. J. Chem. Eng. 1998, 76, 822-827. [CrossRef]

55. Rudzinski, W.; Panczyk, T. Kinetics of Isothermal Adsorption on Energetically Heterogeneous Solid Surfaces: A New Theoretical Description Based on the Statistical Rate Theory of Interfacial Transport. J. Phys. Chem. B 2000, 104, 9149-9162. [CrossRef]

56. Imamoglu, M.; Ozturk, A.; Aydın, Ş.; Manzak, A.; Gündoğdu, A.; Duran, C. Adsorption of Cu(II) ions from aqueous solution by hazelnut husk activated carbon prepared with potassium acetate. J. Dispers. Sci. Technol. 2018, 39, 1144-1148. [CrossRef]

57. Qiu, H.; Lv, L.; Pan, B.; Zhang, Q.; Zhang, W.; Zhang, Q. Critical review in adsorption kinetic models. J. Zhejiang Univ. A 2009, 10, 716-724. [CrossRef]

58. Alguacil, F.J.; Garcia-Diaz, I.; Lopez, F.; Rodriguez, O. Removal of Cr(VI) and Au(III) from aqueous streams by the use of carbon nanoadsorption technology. Desalin. Water Treat. 2017, 63. [CrossRef]

59. Foo, K.Y.; Hameed, B.H. Insights into the modeling of adsorption isotherm systems. Chem. Eng. J. 2010, 156, 2-10. [CrossRef]

60. Alguacil, F.J.; Garcia-Diaz, I.; Lopez, F. The removal of chromium (III) from aqueous solution by ion exchange on Amberlite 200 resin: Batch and continuous ion exchange modeling. Desalin. Water Treat. 2012, 45. [CrossRef]

61. Armbruster, M.H.; Austin, J.B. The Adsorption of Gases on Plane Surfaces of Mica. J. Am. Chem. Soc. 1938, 60, 467-475. [CrossRef]

62. Rahmani-Sani, A.; Hosseini-Bandegharaei, A.; Hosseini, S.-H.; Kharghani, K.; Zarei, H.; Rastegar, A. Kinetic, equilibrium and thermodynamic studies on sorption of uranium and thorium from aqueous solutions by a selective impregnated resin containing carminic acid. J. Hazard. Mater. 2015, 286, 152-163. [CrossRef] [PubMed] 
63. Oyelude, E.O.; Awudza, J.A.M.; Twumasi, S.K. Removal of malachite green from aqueous solution using pulverized teak leaf litter: Equilibrium, kinetic and thermodynamic studies. Chem. Cent. J. 2018, $12,81$. [CrossRef] [PubMed]

64. Hutson, N.D.; Yang, R.T. Theoretical basis for the Dubinin-Radushkevitch (D-R) adsorption isotherm equation. Adsorption 1997, 3, 189-195. [CrossRef]

65. Nollet, H.; Roels, M.; Lutgen, P.; Van der Meeren, P.; Verstraete, W. Removal of PCBs from wastewater using fly ash. Chemosphere 2003, 53, 655-665. [CrossRef]

(C) 2018 by the authors. Licensee MDPI, Basel, Switzerland. This article is an open access article distributed under the terms and conditions of the Creative Commons Attribution (CC BY) license (http:/ / creativecommons.org/licenses/by/4.0/). 